\title{
From Indigenous Customary Law to Diasporic Cultural Heritage: Reappropriations of Adat Throughout the History of Moluccan Postcolonial Migration
}

\section{Gerlov van Engelenhoven ${ }^{1}$ (1)}

Accepted: 19 September 2020 / Published online: 29 September 2020

(c) The Author(s) 2020

\begin{abstract}
Adat is originally an Arabic term meaning "custom" or "habit", and was introduced by Islamic merchants in Maluku and throughout the Indonesian archipelago from the 1200 s onward. The term was used as a way to refer to indigenous customs that could not be incorporated into Islamic law. Therefore, rather than referring to a particular system of customs or laws, adat denoted Islamic law's indeterminate opposite: i.e. the wide variety of indigenous practices which, other than this generalizing label of "custom", remained undefined. Throughout the chapter, I will trace the development of this term from its original usage to its current-day reinterpretation as a form of diasporic cultural heritage by the Moluccan postcolonial migrant community in the Netherlands. As will become clear, the contemporary Moluccan application can be understood as a strategic reappropriation of the term for the construction of their collective identity, which leaves intact the term's original capacity of having no fixed definition. By placing the Moluccan application of adat within the historical context of their separatist ideology vis-à-vis Indonesia, and their migration to the Netherlands in the early 1950s, I will argue that their reappropriation of adat as a deliberately indefinable form of Moluccan cultural heritage can be understood as a way for them to protect their collective identity as a separatist people from becoming a matter of wider contestation.
\end{abstract}

Keywords Indigenous customary law $\cdot$ Maluku $\cdot$ Dutch colonialism · Diasporic identity $\cdot$ Postcolonial migration

Gerlov van Engelenhoven

gerlov.van-engelenhoven@gcsc.uni-giessen.de

1 International Graduate Center for the Study of Culture, Justus Liebig University Gießen, Gießen, Germany 


\section{Introduction}

The Moluccan postcolonial migrant community originated in the Indonesian province of Maluku, and arrived in the Netherlands in the early 1950s. In the aftermath of the Indonesian National Revolution (1945-1949), Moluccans had chosen the side of Dutch colonial rule over Indonesian nationalism, motivated by their, eventually unsuccessful, separatist cause of establishing a Moluccan state, independent from Indonesia. The first generation of the migrant community in the Netherlands consisted of the 12,500 Moluccan soldiers for the Dutch colonial army, and their families. After Indonesia became independent in 1949, these soldiers, due to their separatist ideology, had refused to be demobilized on Indonesian soil. Therefore, in 1951, the Dutch government had brought them to the Netherlands in order to demobilize them there. Their residency in the Netherlands was meant to be temporary, but became prolonged indefinitely due to continuing military conflict between Indonesian nationalists and Moluccan separatists throughout the 1950s and 1960s.

After having lived in a condition of statelessness in Dutch migrant camps for more than two decades, the Dutch government only began integrating the Moluccans into society from the mid-1970s onward, at which point they also received Dutch citizenship. As a result of their initially isolated and marginalized position in Dutch society, Moluccans developed a strong sense of community. In this chapter, I will develop an analysis of what the community considers to be a core element of its collective, diasporic identity, i.e. the concept of adat, or as Moluccan artist Dominique Latoel has expressed it: "our agency and identity are hidden in the adat, which is the right to exist of the Moluccan people and of myself as an individual" ([3]: n. pag.). ${ }^{1}$

Adat is originally an Arabic term meaning "custom" or "habit", and was introduced by Islamic merchants in Maluku and throughout the Indonesian archipelago from the 1200s onward. The term was used as a way to refer to indigenous customs that could not be incorporated into Islamic law. Therefore, rather than referring to a particular system of customs or laws, adat denoted Islamic law's indeterminate opposite: i.e. the wide variety of indigenous practices which, other than this generalizing label of "custom", remained undefined. Throughout the chapter, I will trace the development of this term from its original usage to its current-day reinterpretation as a form of Moluccan cultural heritage. As will become clear, the contemporary Moluccan application can be understood as a strategic reappropriation of the term for the construction of their collective identity, which leaves intact the term's original capacity of having no fixed definition.

In other words, while adat is considered to be a central element of Moluccan identity, what that means, or what adat is, exactly, remains deliberately undetermined. Adat's flexible quality comes across clearly in an article by journalist Jacob Hoekman (Reformatisch Dagblad, 10 May 2010), who, based on his interviews with Moluccans in the Netherlands, notes that adat "refers to time-honored traditional

\footnotetext{
1 My translation from the Dutch original: "De kracht en de identiteit liggen verscholen in de adat, die het bestaansrecht vormen van het Molukse volk en mij als individu.".
} 
Moluccan institutions, customs, morals and folklore. In short: the adat prescribes Moluccans how they are supposed to live, and as such forms the undisputed core of Moluccan identity" (10 May 2010). ${ }^{2}$ Throughout the interview, the term is applied so flexibly, and its definition appears relative to context to such an extent, that, near the end of his article, Hoekman asks himself rhetorically: "Are there, in fact, things that do not concern the adat?" (ibid.). ${ }^{3}$ Correspondingly, anthropologist Birgit [6] describes adat as "originally a holistic concept that cannot be disconnected from any societal sphere", and emphasizes that "there is no single translation or definition for the word [...], it pertains to all aspects of community life" (2015: 44). According to legal scholar Jacqueline Vel [23], "the concept is perceived so naturally that it is like asking a fish to define water" (2008: 66).

This particular application of adat as a flexible concept deviates from ways in which the term has been applied by other parties throughout Indonesian and Moluccan history. In the early twentieth century, Dutch colonial jurist Cornelis van Vollenhoven (1874-1933) approached adat as a pan-Indonesian system of customary laws. His interest in the phenomenon was motivated by the, eventually denied, proposal of the Dutch government in 1904, to unify all law in the colony by installing a centralized system modeled on the Dutch Civil Code. Van Vollenhoven rejected this idea, characterizing it as an attempt at creating "a dominating European law under which all that was still indigenous law [...] would be submerged" ([22]: xxxiv). As an alternative, he argued in favor of a pluralistic system that would incorporate forms of adat next to Dutch law. However, despite this aim to provide colonial subjects with the possibility of legal representation on their own terms, his work was widely reinterpreted after Indonesia's declaration of independence in 1945 in ways contradictory to his original intention. According to legal historian Cees Fasseur [10], Indonesian nationalists viewed "adat as an impediment to further development", and as "fundamentally a Dutch, not an Indonesian, creation" [10].

Whereas the Indonesian nationalist ideology of the mid-twentieth century thus considered adat to be a colonial invention, the term has also been positively reappropriated, especially in the so-called Era Reformasi ("Reformation Era"). This era began in 1998, when President Suharto resigned after 31 years of uninterrupted rule (1967-1998). Since his resignation, "diverse indigenous communities and ethnic groups across Indonesia have publicly, vocally, and sometimes violently, demanded the right to implement elements of adat [...] in their home territories" [13]. Depending from province to province, this "adat revivalism", as Henley and Davidson call it (ibid.), has by turns been "progressive and reactionary, emancipating and authoritarian, idealistic and manipulative" (ibid., 18). Adat revivalists interpret the term not as a colonial inheritance, but invoke it "as a symbol of resistance to the centralized state" [4].

\footnotetext{
${ }^{2}$ My translation from the Dutch original: "Dat begrip duidt op de aloude traditionele Molukse instituties, gebruiken, zeden en folklore. Kortom: de adat vertelt je als Molukker hoe je dient te leven, en vormt dan ook de onbetwiste kern van de Molukse identiteit.".

3 My translation from the Dutch original: "Waar gaat de adat eigenlijk niet over?".
} 
This overview of adat's multiple applications serves as an introduction to this chapter's two main objectives. The first objective is to analyze the legal and political applications of adat during the three abovementioned eras of Indonesian history: (1) the late colonial era, from the beginning of the twentieth century to the declaration of independence in 1945; (2) the era of nationalism and state centralization, during the presidencies of Sukarno and Suharto (1945-1967; 1967-1998); and (3) the current era of decentralization and regionalist state reformation, that has begun after the fall of Suharto's regime in 1998. The second objective is to compare these three historical Indonesian applications of adat to adat's contemporary function as an organizing principle for the Moluccan migrant community in the Netherlands.

Whereas the colonial, nationalist and regionalist applications in, respectively, the early, mid, and late twentieth century, all have in common that they were attempts to reduce adat to a set of clear definitions aimed at instrumentalizing the term for particular purposes of state organization, Moluccan adat in the Netherlands is emphatically understood as something which cannot be defined with universally acceptable characteristics. By placing the Moluccan application of adat within the historical context of their migration to the Netherlands in 1951, I will argue that their reappropriation of adat as a deliberately indefinable form of Moluccan cultural heritage can be understood as a way for them to protect their collective identity as a separatist people from becoming a matter of wider contestation.

\subsection{Adat's Origin as that Which is Not Law}

In his analysis of adat, legal scholar Daniel Fitzpatrick [11] explicitly mentions the concept's "elusive" character, and emphasizes the "tremendous regional variation in Indonesian society" with regard to its particular functions (1997: 176). With that in mind, this section's aim is to explore adat's elusiveness, by analyzing its origins within the long history of Indonesia's colonization.

To begin with, Indonesia has not one, but several histories of colonization. Parts of the area were first subjected to foreign domination from the fifth century $A D$ onward, with the establishment of a succession of Hindu and Buddhist kingdoms and empires linking the territory to Greater India. From the thirteenth century onwards, Persian and Indian merchants arrived, establishing Islamic sultanates in coastal regions, chiefly on the islands of Java and Sumatra in the west of the archipelago, and in the Northern Moluccan territory in the east. Over the next few centuries, these sultanates multiplied, until at the beginning of the seventeenth century, large parts of the Indonesian territory had been converted to Islam. The Portuguese, spreading Catholicism, conquered parts of Maluku from 1511 onward. Finally, the Dutch, introducing Calvinist Protestantism, expelled the Portuguese in 1605, and expanded their colonial rule gradually, until, at the beginning of the twentieth century, it encompassed the full Indonesian territory, then named the Dutch East Indies. Indonesia declared independence in 1945, which incited the four-year Indonesian 
National Revolution. This war ended with the official transfer of sovereignty, in $1949 .^{4}$

Within this succession of different histories of domination, the term "adat" was introduced during the era of Islamic colonization, form the thirteenth century onward. Political scientist Daniel Lev [14] argues that the term was used as a way to refer to indigenous customs that could not be incorporated into Islamic law: "Adat law in Indonesia, as in other Islamic countries, tends to be defined precisely in contrast to Islamic law [...]; it is originally an Arabic word that refers to local custom" ([14]: 27). Therefore, in its early use, adat was not a particular system of law, but rather denoted that system's undetermined opposite: i.e. customs or traditions that were tolerated alongside, but not seen as part of, Islamic law. Lev's description of adat as law's undetermined opposite is significant for two reasons. First, it shows that adat was initially not a concept of indigenous self-description, which is what it has become in the present day. Rather, it was a general label used by foreign dominators to categorize local customs that could not be incorporated into their own law system. Second, and directly following from this, Lev's description provides a basic explanation of adat's elusiveness with regard to fixed definition. Because adat referred to all things beyond the accepted law, its specific definition could take virtually any form depending on context.

This understanding of adat as an unspecific reference to customs not incorporated by central law continued up until the early twentieth century, when Dutch colonial jurists first began to study the phenomenon: "For some, adat law meant any Indonesian law not derived from Dutch or Islamic sources. Others would have disqualified Hindu sources, too. For some, it meant the unwritten law of Indonesia. For others, adat law signified folk law, as opposed to the laws of sultans" [8]. In short, adat could refer to any collection of rules and customs not belonging to whichever system of formal law was in place. To many colonial scholars, adat's apparent incoherence was a reason to discredit the phenomenon as irrelevant to Dutch law, as is showcased in legal scholar Peter Burns's [8] reference to a joke that was common among jurists of the early twentieth century: if you want to know what adat is, "take a concept or a major principle of Dutch law, and inscribe in it the word, "not"' (ibid., 83). The premise of the critique was that adat as such did not exist, but was a negating term used to describe disparate phenomena in terms of what they were not.

This dismissive perception of adat was disputed by Dutch jurist Cornelis van Vollenhoven. Van Vollenhoven [24] argued that adat should be understood not as a vague reference to any customs not incorporated by Dutch law, but as an umbrella term referring to a collection of rules of conduct which "has not been derived from a single source" (1981: 7). To him, the term's apparent lack of a coherent, single definition, was due to the fact that "the influence of history is noticeable. Against

\footnotetext{
4 This summarized history is taken from Herman Burgers. De Garoeda en de ooievaar: Indonesië van kolonie tot nationale staat (7). The summary as it is presented here is rather selective, for instance: the Japanese occupation during the Second World War is not mentioned, and neither is the influence of Chinese merchants since the first centuries AD. The reason for this is that these foreign powers are not directly relevant for the focus of the current section, i.e. the development of adat.
} 
the Malayo-Polynesian background of indigenous beliefs and customs the imprint of Hindu, Moslem and Christian shapes and shades became visible" (ibid.). He elaborates that "the indigenous Malayo-Polynesian law is still the background of the adat law of the Indonesians", into which "there have slipped elements now of Hindu, now of Moslem and now of Christian, origin, or a combination of these elements in areas where Islam has succeeded Hinduism [...] or Christianity Islam" (ibid., 7-8).

In other words, Van Vollenhoven presents adat as a pluralistic phenomenon, that reflects the long history of different, often overlapping forms of domination to which the Indonesian territory was subjected. As such, what sets him apart from his contemporaries is that, for him, adat's apparent incoherence was not a reason to disregard it as "a jumble, an incomplete, inadequate and untidy whole", but instead, to approach it as an "inexhaustible source of instruction" (ibid., 1-2). Because he saw adat's pluralistic appearance as a testament to the territory's multiple histories of oppression, "he regarded every aspect of adat as having indigenous legal significance. Adat was for him a peculiar and pan-Indonesian cultural value system" [8]. Therefore, he proposed that an elaborate study of as many of adat's manifestations as could be found throughout the archipelago, would bring to light patterns and similarities. The following section explores Van Vollenhoven's study of adat further, by contextualizing it within the changing attitude toward colonialism that was impacting Dutch government policy in the early twentieth century.

\subsection{Cornelis van Vollenhoven's Legal Pluralism}

Cornelis Van Vollenhoven became Professor of Constitutional and Administrative Law of the Dutch Overseas Territories and of the Adat Law of the Dutch East Indies, at Leiden University, on 2 October 1901, during what legal scholar Sonius [22], calls "the turn of the tide of Dutch colonial policy" (1981: xxix). Since the early seventeenth century, Dutch domination over their colonies had been characterized by metropolitan rule, the main objective of which was "to exploit the East Indies through agrarian production for the European market", which was carried out "through state enterprises, compulsory cultivation by Indonesians, and large private plantations" (ibid.).

However, in 1901, "after a long and heated debate both in and outside the Dutch parliament, a fresh principle of administrative policy was proclaimed: that of moral responsibility" (ibid.). In September of that year, the newly appointed Prime Minister, Abraham Kuyper (in office from 1901 to 1905), stated that, "As a Christian State, Holland is obliged to suffuse its entire policy with a conviction of moral responsibility to the peoples of these territories" (qtd. in: ibid.). With this pledge, the Dutch government initiated the so-called "ethical policy", i.e. the reinterpretation of colonization as the moral duty of Western civilization, often formulated explicitly as a Christian project (ibid.). The ethical policy presented colonization as a benevolent project, rather than one of exploitation. However, Sonius regards the "benevolence" of this project skeptically, emphasizing that it was formulated "in the face of a rapidly growing nationalist movement" in the colony (ibid.). 
An example of this growing nationalism was the Aceh War (1873-1904), which was fought between the Netherlands and the sultanate of Aceh, on the island of Sumatra in the west of current-day Indonesia. This war had proven that directly oppressive forms of colonial domination were starting to give rise to structural resistance oriented toward independence. The Dutch ethical policy was developed during the last years of this war, and can be understood as a "softer" form of domination, that is, as an attempt to retain the colonies without the use of military violence. As such, this new approach to colonialism was built from an ambivalent premise, since on the one hand, it claimed to be "aimed at the emancipation or elevation of the indigenous population" [10], but on the other hand, it pursued this direction in order to justify the fact that the Netherlands remained in possession of a territory that was struggling for independence.

This ambivalent premise of the ethical policy explains why the emancipatory measures which the Dutch government had in mind often entailed further centralization, rather than decentralization, of colonial rule. For instance, a prominent advocate of the ethical policy, the politician and lawyer C.Th. van Deventer, "saw a direct link between unification of law and common prosperity; the latter was not really possible without the former. Only Western law could ensure judicial certainty for the indigenous people, and industry and commerce would follow in its footsteps and flourish" (ibid., 59). In this citation, Van Deventer presents the unification of local law based on the western model explicitly as a necessary step toward more prosperous circumstances for colonial subjects. As such, it is an example of how proposals toward the centralization of colonial rule were expressed as serving the ethical policy, as a way to justify the continued Dutch possession of the Indonesian territory.

In 1904, inspired by this perspective on colonial jurisdiction, A.W.F. Idenburg, the Minister for Colonial Affairs at the time, "introduced a bill which would make it possible to codify the substantive private law for all population groups in Indonesia on the basis of the Dutch Civil Code" ([22]: xxxiii-xxxiv; italics in original). The socalled Idenburg bill incited a "fierce discussion about the advantages and disadvantages of the introduction of modern and uniform European law concepts into native societies and of the suppression or conservation of [...] adat law in Indonesia" [10]. The problem with adat, argues Cees Fasseur [10], was that so little was known about it: "A systematic description and analysis of Indonesian adat law really got under way only after the appointment of Van Vollenhoven to the Leiden chair of adat law of the Indies in 1901" (ibid., 50-51).

In this capacity, Van Vollenhoven became a prominent voice against legal unification, and in favor of incorporating adat into a pluralistic law system. He advocated an integrated system of law, to which everyone, Dutch and Indonesian, would be subjected, and in which adat and European law would be applied together. In order to develop this system, he believed that more knowledge about adat had to be acquired: "good government and a good administration of justice [...] are unthinkable without a thorough knowledge of indigenous law and indigenous conceptions" ([22]: xxxvi). In pursuit of this aim, he established the Commission for Adat Law in 1909, which "set out to publish systematic collections of widely dispersed adat law data. Most of these were published in the Adatrechtbundels (45 volumes since 1910)" (ibid., lvii). 
Van Vollenhoven's pluralistic position was eventually adopted by the government in 1919, with priority even shifted toward adat rather than European law. According to article 75 of the government regulation for the colony of that year, "Only when the needs of native society required it [...] could European law be declared applicable" [10]. Although this may seem to have been a victory on behalf of Van Vollenhoven, Fasseur emphasizes that the article also stated that, for this pluralistic arrangement to work, "adat law should be codified" (ibid., 60). In other words, in order to incorporate adat into colonial jurisdiction, it had to be translated into an applicable system that would be comprehensible to Dutch legislators.

However, this task was not easy to fulfill. The problem with codifying adat, as Daniel Fitzpatrick [11] explicates, is that as a normative practice, it resists

analysis based on Western notions of enforceable "rights" and "obligations". Instead, the regulation of adat communities, and the interaction of those communities with other adat groups, rests squarely on traditional processes of deliberation and consensus (mufakat and musyawarah) and mutual assistance (gotong royong). ([11]: 179)

In concurrence with these considerations of adat's negotiable and situational character, Sonius [22] asks rhetorically: "How could one ascribe to adat law a body of objective and preexisting rules if the conciliatory nature of adat justice made it constantly necessary for adat judges to 'find' or 'create' the law applicable in individual cases?" ([22]: xlviii). These remarks present adat as a multiplicity that is detectable only in its singular applications to particular situations. Taken as such, its codification would be a contradictory project to the extent that it implies universalizing into generally applicable rules an intrinsically non-universalizable phenomenon.

Despite being aware of these contradictions, Van Vollenhoven himself had attempted a basic codification of adat law in 1910. The result, argues Fasseur [10], was "too rudimentary an edifice to give a satisfying answer to the question of how adat law could be made operational in practice" ([10]: 61). This guideline for the judge "was in reality the proclamation of his complete freedom to invent the law that, depending on the circumstances, suited people most" (ibid., 61). Moreover, Van Vollenhoven further complicated the purpose of adat's codification by suggesting that one single code would not do justice to the reality of Indonesia's multi-ethnic and multi-religious constellation. Instead, he estimated that about twenty local codifications "would be needed to chart the complex and highly diverse legal situation in the whole of Indonesia" (ibid., 58). Additionally, he argued that each adat codification would have to be "abrogated automatically after ten or fifteen years in order to force the administration continuously to adapt the adat regulations to new developments and changed circumstances in native society" (ibid.).

None of these suggestions seemed realistic to "government officials or to practicing lawyers who were looking for an immediate solution to their many questions" (ibid.). Even Van Vollenhoven himself gradually developed a point of view that disregarded the possibility of codification entirely, fearing that "it might stifle a harmonious development of native customs and institutions" (ibid., 61). This point of view informed much of his output in the years after the official declaration of the pluralistic system in 1919. Van Vollenhoven and his students, 
collectively known as the Adat Law School, "were committed to resisting every step that would allow adat to undergo the painful transmutation into formal law" [8]. The result was a stalemate. Despite the agreement between the Dutch government and the Adat Law School concerning adat's incorporation into the colonial law system, neither party had a feasible proposal as to how to realize this aim. According to Sonius [22], this stalemate was symptomatic of a dilemma that lay at the heart of Van Vollenhoven's project. The project was motivated, on the one hand, by "a desire for the sake of legal certainty to provide adat law with a formal criterion (the judicial decision, jurisdiction), and, on the other, by a fear that such a criterion would unduly restrict the meaning of operative adat law" ([22]: xlix).

The unfortunate effect of this stalemate was that despite the objective of the post-1919 pluralistic system to prioritize adat law over Dutch law, in practice, the unstable status of adat as adaptable local law would often instead subject it to Dutch law: "In all circumstances the authority of the adat was made to bend to that of Dutch criminal and civil law whenever the two overlapped" or whenever they "came into conflict" (Jaspan 1965: 254). Political scientists David Henley and Jamie S. Davidson [13] formulate this practical reality of the pluralistic system in a directly critical way. According to them, the incorporation of adat into colonial rule often entailed the strategic "reinforcement by the state of internal hierarchy within the 'adat communities' themselves" ([13]: 24). The official recognition of adat enabled a form of indirect rule, which Henley and Davidson define as "The practice of ruling via existing leaders, backing up their authority with the power of the state in return for their compliance in using that authority for the state's purposes" (ibid.).

A concrete example of such adat-based indirect rule is the fact that Dutch officials used the pluralistic system to cast local leaders as so-called "adat chiefs". These chiefs functioned as what Henley and Davidson call "Client (or puppet) leaders", seeing that their "right to rule-and judge according to adat lawrested neither on the state nor in a direct way on the popular will but rather on the authority of custom" (ibid.). This was "a more abstract source of legitimacy", that appealed to the local population's sense of autonomy (ibid.). This perspective presents the reality of Van Vollenhoven's envisioned plurality as a form of, often quite overt, political manipulation: "Such was the confidence of Dutch officials in their own understanding of what Indonesian custom entailed that in extreme cases they even created, by a procedure referred to as adatontwikkeling or 'development of custom', new types of 'popular' chief (volkshoofd) at levels where none had previously existed" (ibid.).

In short, what was practiced as adat in the colonial courts were to great extent new constructs, which more often than not were instrumentalized within a larger strategy of indirect rule. This implies that adat was not used to open up space for indigenous legal subjectivities, which is how Van Vollenhoven had envisioned it. On the contrary, the application of adat within the colonial law system enabled the continuation of colonial oppression. The following section will further develop this idea of adat as a colonial product, by shifting the focus to the first decades after the Indonesian declaration of independence in 1945, and analyzing adat's changed role within this era, as a central element of the construction of a nationalist identity. 


\subsection{Adat's Function for Indonesian Nationalism}

That the application of adat as law was more a Dutch than an Indonesian affair, becomes clear when considering that "Rudimentary legal training for Indonesians was not introduced until 1909", i.e. 5 years after Idenburg had proposed to unify colonial law [10]. Moreover, "A complete law faculty was opened in Batavia only in 1924", that is, 5 years after the Idenburg bill had been withdrawn in favor of an, albeit poorly executed, version of Van Vollenhoven's vision of a pluralistic system (ibid.). As such, the version of adat that was practiced in the colony must be understood as a particular adaptation of the concept, provided with meaning through its appropriation by Dutch colonial legislators. This section follows up on this consideration, by analyzing how adat's function as a colonial instrument changed when Indonesian nationalists reappropriated the concept after the declaration of independence in 1945.

In order to understand this gradual change of adat's application in post-independence Indonesia, the initial influence of Van Vollenhoven's Adat Law School must be noted. Cees Fasseur [10] relates that in 1942, when the Japanese invasion of Indonesia instigated the process of the dissolution of Dutch colonial rule, the colony had a grand total of 194 professional advocates, of whom 36 were Indonesians (ibid.). Although this equates a percentage close to twenty percent, Fasseur emphasizes that the most influential "of these Indonesian lawyers had received their university training in the Netherlands, in particular at the University of Leiden, for want of an Indonesian academic alternative" (ibid., 63). All of these Leiden alumni had written their doctoral dissertations "under the supervision of Van Vollenhoven or his close colleagues" (ibid.). Among them was Supomo, who would become "the first republican Minister of Justice in independent Indonesia after 1945", and "who drafted the constitution of the new state" (ibid.).

In other words, of the small number of Indonesian jurists that were employed near the end of colonial rule, a majority were students of the Adat Law School. Moreover, not only the Indonesian jurists were often Leiden-trained, most Dutch jurists practicing in the colony had studied in Leiden as well. Many of Van Vollenhoven's Dutch students "reached high positions in the colonial bureaucracy since, from 1902 on, Leiden University had the monopoly of the training and education of future Dutch civil servants for the East Indies administration" (ibid., 51). This means that even Indonesian jurists who were not trained in Leiden, were probably still trained by Van Vollenhoven's former students. For example, the chair of adat law at the law faculty of the colony's capital, Batavia, was occupied by one of Van Vollenhoven's most prominent students, Bernard ter Haar, who was responsible for authoring the first standard work on adat to be translated into English. ${ }^{5}$

According to Daniel Lev [16], this dominant presence of Leiden alumni in Indonesian legal practice was one of two important reasons for the fact that the

\footnotetext{
5 The book was called Beginselen en Stelsel van het Adatrecht (1939). Its English translation, Adat Law in Indonesia, was published in 1948. Fasseur stresses that this was "the first time that a major work on adat law was made accessible to readers who did not understand Dutch" ([10]: 65).
} 
Indonesian republican government, which was established in the months after the declaration of independence in 1945, initially continued the plural law system without any fundamental changes: "most officials in the new state, particularly public lawyers in the administrative and judicial bureaucracies, took plural law and plural society for granted as the only working model they knew" ([16]: 70). However, Lev's second, more elaborate, reason to keep legal pluralism in place proves that the problematic colonial legacy of this system did not go unnoticed:

without an obvious alternative, unifying the law seemed to demand a painful choice between the codes and adat as the conceptual base. The codes were attractively "modern" but symbolically "European", and might still work to the advantage of European [...] commerce. Adat, which had been used to keep Indonesians in their place, could by slight turn of imagination become a nationalist symbol of their distinctiveness, but it was generally regarded as too primitive [sic] for the law of a modern state. The dilemma favored the legal status quo until there was time to resolve the issues. (Ibid.)

This citation indicates that post-independence adat provided two opposing connotations at the same time. On the one hand it was seen as a colonial heritage, but on the other hand as something distinctly "Indonesian".

The influence of the Adat Law School on early nationalist discussions about adat becomes clear when considering that not only the first, but also the second of these connotations can be traced back to Van Vollenhoven's legacy. The idea of adat as an inherently Indonesian phenomenon was due to Van Vollenhoven's argument that underlying the wide variety of local applications, "there was a single, basic, Ur-adat common to all regions of the Indonesian culture area" [8]. According to political scientist David Bourchier [4], this argument "provided the basis for imagining the islands of Indonesia as a coherent culture area and thus a coherent nation. In this way adat, and the communitarian values it was associated with, came to be thought of as the essence of the Indonesian national personality" (2007: 115). However, whereas "adat", as an idea, was thus frequently invoked as an abstract appeal to national unity during these first years after the declaration of independence in 1945, the republican government meanwhile began to systematically nullify the concrete legal practice of adat. For instance, adat courts, which had functioned as so-called native courts within the pluralistic judiciary system, "were abolished during the war and during the years of revolution that followed" [10].

Lev [15] provides an example of the rationale behind the abolishment of the adat courts when he refers to a working paper entitled "Towards the Abolition of Native Courts and Judicial Unification in South Sumatra", that was written by former state secretary Alwi, and sent to the Indonesian Ministry of Justice in 1950. According to Alwi,

adat courts had not fulfilled the conditions of good justice. They were not based on a separation of functions, nor were they bound by written codes [...]. The adat courts were guilty of arbitrariness, and they provided no legal certainty. [...] Moreover, as the customary courts were not bound by common 
rules of procedure and substantive law, the law varied from area to area, and this too increased legal uncertainty. (1973: 28)

These criticisms against the practice of adat law to a great extent resemble the general argumentation of the Dutch colonial government in the early twentieth century. Before Van Vollenhoven had implemented the plural law system in 1919, the Dutch government had been in favor of unified law in the colony. This point of view, much like Alwi's, was based on the colonial government's interpretation of adat as an incoherent and arbitrary system that provided no legal certainty. Like the pre-1919 Dutch government's criticism of adat, Alwi's criticism in 1950 also culminated in the appeal for legal unification, as he proclaims at the end of his paper: "One kind of law and one kind of court for all the people of Indonesia" (qtd. in: ibid., 29).

Alwi's appeal was one of many signs that nationalists favored legal unification, as pluralism was now understood as "a legacy of Dutch efforts to keep Indonesians divided along racial and ethnic lines" [4]. However, the fact that nationalist lawyers understood the particular practice of adat law as it existed in 1945 to be a colonial legacy, did not imply that they saw adat as such as a colonial invention. Rather, they presented it as an originally Indonesian concept that had been appropriated and manipulated by colonial power. As such, in their development of a unified national law system, their objective was to detach adat from its colonial inheritance, and appropriate it as a national symbol.

This new, specifically nationalist function of adat, becomes apparent when studying the way in which President Sukarno (in office from 1945 to 1967) justified Indonesia's transition from the parliamentary democracy which had been in place since 1949 , to the so-called Guided Democracy which was initiated in 1959. According to Bourchier [4], Sukarno explained this autocratic revision of society "squarely in terms of the need to move towards a more indigenous system of rule based on the village practices of musyawarah (deliberation) and mufakat (consensus). In so doing he brought indigenist rhetoric back to centre stage" (2007: 119). Therefore, while concrete adat practice was being repressed, the term "adat" gained significance as an abstract appeal to Indonesian cultural heritage, and was in that symbolic capacity "readily available [...] both for instrumental and legitimatizing purposes" (ibid.).

This split in adat's function, as a nationalist ideal on the one hand, and the concrete practice of local law on the other, increased further when Suharto succeeded Sukarno as Indonesia's second president in 1967, ushering in the so-called Orde Baru ("New Order", 1967-1998). One of Suharto's main concerns "was to legitimate the New Order in cultural terms, to assure the millions of Sukarno sympathizers in particular, that the New Order was at least as authentically Indonesian as the old regime" (ibid., 120). To pursue this aim, he developed the P4 program (Pedoman Penghayatan dan Pengamalan Pancasila: "Guidelines for the Understanding and Implementation of Pancasila"), i.e. a mandatory education program for all of Indonesian society, first introduced in $1979 .^{6}$ The program was not only incorporated

\footnotetext{
6 Pancasila (Old Javanese for "Five Principles") is the Indonesian state philosophy, first developed under Sukarno's rule. The five principles are (1) "the belief in one supreme being"; (2) "the commitment [...] to a just and civilized humanitarianism"; (3) "a commitment to the unity of Indonesia"; (4) "the idea of a people led or governed by wise policies arrived at through a process of consultation and consensus"; (5) "a commitment to social justice for all the Indonesian people" (Morfit, 1981: 840). According to Michael
} 
into primary, secondary and tertiary education, but also became obligatory for "all civil servants below the rank of cabinet minister" (Morfit, 1981: 838). Its purpose was

to inscribe on the population a way of thinking about being Indonesian that was intimately tied to the conservative image of traditional society promoted by adat scholarship. In tying Indonesian-ness to generic "adat norms" in this way, the government was able to declare behaviors that it did not approve ofincluding opposition, striking, and voting in parliament — to be un-Indonesian. [4]

This citation indicates how Suharto's regime appropriated adat and turned it into an exclusionary concept. This version of adat was utilized to portray Suharto's political opponents as cultural outsiders, who, through their refusal to comply to-his definition of - "adat", had proven that they were essentially not Indonesians.

However, while thus transforming adat into a form of propaganda, Suharto also furthered national unification, for example by issuing Village Law No. 5/1979, which resulted in the standardization "of governmental structures all over Indonesia from the top down to the village level" [6]. This process was referred to as "Javanization", i.e. the restructuring of the entirety of Indonesia's multi-ethnic and multireligious society on the basis of the model operative on Suharto's birth island of Java (ibid.). By centralizing Java as the heart of the Indonesian identity, this process was detrimental to innumerous local customs throughout the archipelago: "Culture was folklorized and local traditional structures and functionaries at the village level were depoliticized, marginalized, deprived of their meaning, co-opted, or replaced by village heads installed or at least approved by the state" (ibid.).

In short, Suharto's regime essentialized adat as the symbolic heart of Indonesian identity, while suppressing diverse concrete forms of local adat practice. As such, Suharto's appropriation of adat continued the practice of instrumentalizing the concept for political reasons, that had begun with the initiation of the pluralistic colonial law system in 1919. Whereas the colonial application of adat had enabled indirect rule, Suharto's intention was to replace adat's function as a collection of concrete, local forms of authority, by an abstract, state-led ideology of national unity. That this intention was not entirely fulfilled becomes clear in the next section. As I will argue, during the Era Reformasi, which began with Suharto's resignation in 1998, local applications of adat persisted and became pivotal in the development of postSuharto, indigenous identities.

Footnote 6 (continued)

Morfit [18], the Pancasila philosophy provides "an important ideological justification" for the policies of the New Order government, where especially the fourth principle resembles adat's emphasis on consultation (musyawarah), and consensus (mufakat) (ibid., 839). 


\subsection{Adat's Function During the Era Reformasi}

Near the end of his overview of Van Vollenhoven's legacy in contemporary Indonesia, Sonius [22] offers a brief insight into Indonesian society's legal situation during the $1980 \mathrm{~s}$, and the position of adat within it: "Today, [...] Adat law has no institutions which could enable it to operate effectively outside the sphere of the local communities, or to prevent the abuse of foreign concessions" (1981: xxxviii-xxxix). Peter Burns [8], who, like Sonius, wrote during the height of Suharto's New Order regime, agrees with him, and elaborates:

Meanwhile, the rural masses of Indonesia enjoy no greater certainty of either law or rights than did their ancestors in the years when Van Vollenhoven was first moved to defend their interests. Now, as then, a central government is concerned to encourage foreign capital to develop the natural resources of the land, but adat law no longer functions as a weapon which might be employed to resist over-exploitation. (1989: 110).

These citations indicate that legal scholars in the years before the Era Reformasi (1998 onward) believed that adat had lost all of its practical significance, as a result of it being continuously appropriated as an instrument of state control: first by the colonial, and after that by the Indonesian nationalist governments of Sukarno and Suharto.

However, Daniel Fitzpatrick [11], who published his study one year before the fall of Suharto's regime, argues that, although Suharto has worked systematically toward "the destruction of adat authority", it may nevertheless "continue to exist as a network of shared values and relationships. [...] In fact, in many areas it has become an expression of regional identity against the pervasive social, economic, and governmental influence of the Javanese" (ibid.). In other words, according to Fitzpatrick, adat never completely lost its regional functions, despite state efforts to nationalize the concept. The fact that Suharto's regime suppressed these regional functions does not mean that they could not resurface again if the political situation would change.

As it indeed turned out, the fall of Suharto's New Order, in 1998, initiated processes of "decentralization, and the reconstitution of the original precolonial autonomy of local communities" [6]. These post-Suharto reforms indicate that adat's function, which had been reconfigured twice since the beginning of the twentieth century, was changing again. First, with the installation of plural law in 1919, adat had been used as an instrument of indirect rule by colonial legislators. Subsequently, from the declaration of independence in 1945 onward, the concept had been turned into a nationalist instrument of state centralization during Sukarno's and Suharto's presidencies. Now, since the fall of Suharto's regime in 1998, the focus on local autonomy suggests a new configuration of adat as an instrument of indigenous emancipation from state control. The collapse of the New Order "allowed the return of the repressed, the other side of adat, the claims to provide a normative base for a local political community independent of the state" ([5]; italics in original).

An important step toward this envisioned decentralization was the founding of the Indonesian Human Rights organization AMAN (Aliansi Masyarakat Adat Nusantara, 
translated by the organization itself as "Indigenous Peoples Alliance of the Indonesian Archipelago") in 1999. As becomes apparent from comparing the Indonesian name of this NGO to its English name, "indigenous peoples" is the official translation used for masyarakat adat (literally: "adat peoples"). According to Birgit Bräuchler [6], this choice of terminology "intimately ties the question of indigeneity to the (revival of) adat discourse in Indonesia" (2015: 57). The group was founded during the First Congress of Indigenous Peoples of the Archipelago in March 1999, and gained national attention when they, supported by "more than two hundred representatives of adat communities scattered across Indonesia from Aceh to Papua", made a public threat "not to recognize the authority of the Indonesian state if the state did not recognize theirs" [13]. ${ }^{7}$

This threat was effective, to the extent that it resulted in "a raft of new national and regional legislation recognizing traditional customary rights" [4]. The most important new laws in this context were Laws Nos. 22/1999 on Local Government, and 25/1999 on Regional Autonomy. These laws "allowed specifically for internal institutional reform at village level, highlighted the importance of local adat in village governance", and obliged administrators at district levels to "recognize and honor the rights, origins and customs and traditions of the village" [13].

These reforms show that AMAN was successful in propagating a nation-wide celebration of regional diversity under the adat banner. Although this may seem like a fortuitous development for local communities, especially in the aftermath of Suharto's 31 years of centralized rule (1967-1998), David [Bourchier [4]] is critical of AMAN's version of adat. According to him, the effectiveness of this project was questionable, "due to the fact that their representations of adat as wise, socially harmonious, communalistic, and in tune with nature chimed with one of the favorite themes in Indonesian political thinking, the idea that adat is inherently good, pure, and authentic" (2007: 123). As such, while AMAN reappropriated adat in order to strengthen indigenous authorities against the centralized state, it did so without critically reassessing the connotations which the state had provided the term with: AMAN "adopted quite unselfconsciously the romantic imagery of 'adat' that had been a staple of conservative political ideologues in Indonesia for decades" (ibid.).

This uncritical continuation of adat as a rhetorical term utilized to invoke the image of peaceful communitarianism, led AMAN "to push for the introduction of legislation empowering adat communities as if they existed as distinct, harmonious, self-regulating entities" (ibid.). However, the concrete practice of local adat had been undermined by the Indonesian government for the last half century in favor of an intentionally vague, symbolic meaning indicating national unity. Therefore, by the time AMAN was founded in 1999, adat had become "a generic term to indicate an often undifferentiated whole constituted by the morality, customs, and legal institutions of ethnic or territorial groups" (Franz and Keebet von Benda-Beckmann [2]: 168). As such, the result of AMAN's campaign was not the massive indigenous emancipation which the organization had envisioned. Instead, the new laws induced

\footnotetext{
7 Aceh and Papua are regions in, respectively, the far west and the far east of Indonesia.
} 
a large number of "internal disputes over the different interpretations of local adat", showcasing "the power of definition and representation" [6].

An example of these disputes can be found by studying the details of Law No. 25/1999 on Regional Autonomy. In order to claim the rights provided by this new law, villagers had to "provide proof for being a traditional adat community/village" (ibid., 49). Bourchier [4] scrutinizes this obligation by asking: "What is an adat community?" (2007: 123). AmAN defined it in 2001 as a "community living together based on their origins intergenerationally in adat land, who have sovereignty over the land and the natural resources", and whose sociocultural life is "regulated by adat law and adat institutions which manage the sustainability of the communities' lives" (qtd. in: ibid.; italics added).

This definition, rather than clarifying the meaning of an adat community, invokes more adat-related concepts in need of explanation: "adat land", "adat law" and "adat institutions" are all terms that are used differently by different parties, and are dependent upon context. The result is, that "In practice, an adat community is a group that describes itself as an adat community" (ibid.). As such, a large variety of groups of people have defined themselves in these terms for myriad political purposes, many of which are radically different from AMAN's originally democratizing and emancipatory aims: "the adat revival has sparked the emergence of ethnonationalisms and other-sometimes violent-manifestations of chauvinism that are difficult to square with the progressive aims of the NGO activists leading the adat movement" (ibid.).

David Henley and Jamie S. Davidson [13] offer a concrete example of these negative outcomes of the new adat legislations: "In Kalimantan, where indigenous Dayaks have participated in a series of pogroms against migrant Madurese communities, acts of horrific violence have been carried out - or at least justified - in the name of adat" (2007: 28). ${ }^{8}$ Another example is the sectarian conflict that took place in Maluku between 1999-2002: "Adat councils in the Moluccas have been implicated in sectarian violence and the destruction of property that has killed and displaced tens of thousands of people" [4]. According to Bourchier [4], these cases prove that violent conflict is the inescapable outcome of "supporting adat as a vehicle for mobilizing people", because "it sharpens distinctions between cultural insiders and outsiders, increasing the potential for horizontal conflict and violence" (ibid.).

Apart from these instances of violence between communities, regional appropriations of adat have also affected the distribution of power within communities: "There is already evidence of conservative elites using the new opportunities afforded by the resurgence of adat to reinforce their power at the expense of less privileged groups" (ibid.). Moreover, adat revivalism has also increased the inequality between men and women in Indonesian society: appeals to adat as a basis for political legitimacy and organization "tend to privilege elites, especially senior men, who are empowered to speak on behalf of a presumed whole" [17]. Henley and Davidson [13] elaborate that "the disempowerment of women is often a particularly visible-and for

\footnotetext{
${ }^{8}$ Kalimantan is an island in the west of Indonesia. Dayaks are the indigenous people of Kalimantan. The Madurese people on Kalimantan originate from Madura, which is another island in the west of Indonesia.
} 
international supporters of the movement, particularly embarrassing — by-product of its enthusiasm for traditional institutions and ways of thinking" (2007: 26-27).

These problematic results of adat's revitalization have not remained unnoticed. As Bräuchler [6] relates, "These negative developments motivated the central government to partly take back local autonomy again with the revised law No. 32/2004", five turbulent years after the original decentralization laws were formulated (2015: 52). This law, concerning Regional Autonomy, declared that "the state acknowledges and respects adat law communities and their traditional rights as long as they are still alive and in accord with societal developments and the principle of the Unitary State of the Republic of Indonesia" (qtd. in: ibid., 54). In other words, after the opening up of adat's meaning to regional definitions had caused unexpected conflicts between and among self-proclaimed adat communities, the state decided with Law No. 32/2004 to resubordinate adat to a secondary form of authority, only to be invoked in situations where that would not be in conflict with the state's purposes.

The specific way in which this law formulates its acknowledgment of adat constricts it to a marginal place from where it cannot stand in the way of formal law. Before the Era Reformasi, this type of formulation was already used in the centralization laws that were developed during Sukarno's and Suharto's presidencies. For instance, the Basic Agrarian Law (BAL) of 1960 stated that its rights were based upon adat, but only "insofar as it is consistent with national unity, the interests of the state, and the provisions of the BAL itself" [11]. Before independence, this strategic approach to adat was also already used in the colonial government's adaptation of Van Vollenhoven's pluralistic vision in 1919, where, "In all circumstances the authority of the adat was made to bend to that of Dutch criminal and civil law whenever the two overlapped" or "came into conflict" (Jaspan, 1965: 254).

In fact, this marginalizing approach to adat even predates Van Vollenhoven's time. For instance, in 1814, the Lieutenant-Governor of the Dutch East Indies, Thomas Raffles, issued an order about legislation on Java, declaring that a judge "shall be guided in his decisions by existing native laws, and ancient customs of the Island; provided the same be not decidedly at variance with the universal and acknowledged principles of natural justice" (qtd. in: ibid., 255). According to Bräuchler [6], the particular space given to adat in legal formulations such as those mentioned above "always leaves a back door open for the government in case the different normative orders clash or in case there would be economic disadvantages for the government" (2015: 54). Thus, adat is acknowledged up until the point that this ceases to be convenient to central rule.

This long history of limiting adat's authority suggests that the term has perhaps not ventured that far from its origin in the thirteenth century, as an unspecific reference to all customs not belonging to Islamic law. Throughout Indonesian history, adat has been tolerated alongside whichever central rule the territory was subject to. As such, the concept's limits have been defined in many different ways: adat's authority is usually described to end there where it would otherwise clash with formal law. Adat itself, meanwhile, has proven to remain resistant to any lasting definition. This becomes apparent when considering that, following the declaration of Law No. 32/2004, new attempts to codify adat law in village regulations have been without significant success: 
A World Bank team assessing the engagement of non-state justice in Indonesia consulted villagers for their opinion and faced the same dilemmas as the Dutch adat scholars in the past: while most of their respondents on the ground said that "codification was necessary for legitimacy and external recognition of adat law", others rejected it as contrary to the dynamic and contested nature of local norms and adat. (Ibid., 54)

This citation indicates that, as was the case in Van Vollenhoven's time, the codification of adat is met with skepticism, because of the risk it presents concerning the loss of its flexibility: the problem with turning adat into formal law is "how to fix it and at the same time preserve its flexibility so as to allow its adaptation to changing sociopolitical circumstances" (ibid., 180). However, the alternative to codification is to apply adat without codifying it or otherwise using the state's central authority to fix its definition into a nation-wide consensus. But, as has been discussed, this grassroots approach was attempted with the laws on Local Government and Regional Autonomy in 1999, and resulted in violent conflicts throughout Indonesia, due to the widely varying and often contradictory local interpretations.

While considering the unsatisfying results of both of these approaches to adat, i.e. fixing it into a definitive meaning or applying it without such fixed definition, Bräuchler concludes that a more productive question to ask with regard to the phenomenon concerns "who is doing the fixing, and who is defining what traditions need to be fixed" (ibid., 180-181). In other words, her suggestion is to approach adat as an indicator of power: "In order to avoid one-sided political manipulation or instrumentalization of (reinvented) collective identities and traditions, it is important to find out who is speaking for whom and who claims to represent whom" (ibid., 207). The way in which adat is defined in a specific context of time and space usually indicates which parties are involved and how power is distributed among them.

With that in mind, the next section will focus on how adat traveled to the Netherlands with the first generation of Moluccan migrants in 1951, and how it was developed within the context of this community's marginalized position in Dutch society. By analyzing the development of adat within this historical context of migration and marginalization, I will show how the Moluccan community has appropriated and reconfigured adat as a form of Moluccan cultural heritage that lies at the foundation of their collective identity as a separatist people, identifying neither as Dutch, nor as Indonesian.

\subsection{Adat's Function within the Moluccan Community}

The particular application of adat by the Moluccan community can be understood by placing it within the context of the community's migration history. ${ }^{9}$ The migration was a result of the Moluccan separatist struggle, which motivated their recruitment for the Dutch, rather than the Indonesian army during the Indonesian National

\footnotetext{
9 My historical overview of the Moluccan migration is based on Fridus Steijlen, RMS: van ideaal tot symbool. Moluks nationalisme in Nederland, 1951-1994 (1996).
} 
Revolution (1945-1949), as well as their attempt to establish an independent Moluccan republic. The RMS (Republik Maluku Selatan: "Republic of South-Maluku") was unilaterally proclaimed on the Moluccan island of Ambon, on 25 April 1950. The political leaders who were responsible for this proclamation had based their actions on a separatist interpretation of adat. For instance, the Moluccan Minister of Defense, Alex Nanlohy, "had developed an adat-based Ambonese nationalism, as much anti-Dutch as anti-Javanese" [9]. ${ }^{10}$ In other words, Nanlohy's interpretation of adat functioned as the basis for Moluccan separatism, setting them apart both from the Dutch colonial past and from the Indonesian independence ideology that was developing in Java. ${ }^{11}$

A different aspect of Moluccan adat was mentioned by the Moluccan Minister of Information, D.Z. Pesuwarissa, in an interview with Radio Ambon on 24 April 1950, the day before the proclamation. During this interview, Pesuwarissa emphasized that the Moluccan Republic "is neither Islamic or Christian, because in the Moluccas the relationship between Islam and Christianity is like that of brothers", to the extent that both communities "have the same family names and share the same adat-istiadat and culture" (qtd. in: ibid., 371). ${ }^{12}$ As such, whereas Nanlohy emphasized the separatist element of Moluccan adat, Pesuwarissa stressed its reconciliatory function as a "means to bridge the religious divide" between Christianity and Islam in Maluku [6].

Therefore, in its origin, Moluccan adat differed both from Van Vollenhoven's colonial version in the first half of the twentieth century, and from the nationalist version that was developed during Sukarno's and Suharto's presidencies throughout the second half of the twentieth century. Whereas these versions have in common that they saw adat as a pan-Indonesian cultural value system, Moluccan adat was in fact presented as something that separated them from the rest of Indonesia. To that extent, it can be understood as an early variant of the regionalist approach that became common throughout Indonesia after the fall of Suharto's regime in 1998: it was invoked as an appeal to regional autonomy rather than national unity.

However, what sets Moluccan adat apart from all the other variants that have been discussed, is that it traveled from Indonesia to the Netherlands in 1951, along with the first generation of Moluccan migrants. From that moment onward, this particular type of adat was developed independently from adat in Maluku. The latter evolved much along the same lines as other forms of adat in Indonesia. During the Sukarno and the Suharto presidencies, it was stripped of its concrete legal validity and simultaneously essentialized as a symbol of national unity. After Suharto's resignation in 1998, its function as a form of local autonomy was revived by the indigenous activist organization AMAN, alongside the innumerous other forms of adat found

\footnotetext{
${ }_{10}$ Because Ambon is Maluku's central island, and the location from which the independent Moluccan state was proclaimed, the terms "Ambonese" and "Moluccan" were used interchangeably at the time.

11 Cf. President Suharto's project of "Javanization", i.e. the standardization of "government structures all over Indonesia from the top down to the village level" based on Javanese society [6].

12 The suffix "-istiadat" can be translated as "tradition". As such, the term "adat-istiadat" signifies a pleonastic articulation along the lines of "adat tradition" or "customary tradition".
} 
throughout the Indonesian archipelago. Like elsewhere in Indonesia, this revival had adverse effects in Maluku, to the extent that it resulted in widespread sectarian violence between 1999 and 2002.

Meanwhile, the adat of the Moluccan community, living in migrant camps throughout the Netherlands, did not evolve along these lines. To the contrary, its particular development reflects the history of the community's first generation, i.e. the Moluccan soldiers for the colonial army. According to anthropologist Dieter Bartels [1], a majority of these soldiers "had left their home villages in their teens and twenties", and about "one-tenth of them had been born outside the Moluccas", in barracks stationed elsewhere in Indonesia (1986: 30). In other words, these soldiers, though ethnically Moluccan, had been separated from their place of origin early in life, and had been stationed in different locations throughout Indonesia in the service of the Dutch colonial army. As indicated by the one-tenth which Bartels mentions (see citation above), it was not uncommon for these soldiers to come from a longer lineage of soldiers, as a result of which many of them had never even been to Maluku, but instead had been born and raised in the army barracks throughout Indonesia. According to political historian Richard Chauvel [9], "This type of internal recruitment seems to have been preferred by the authorities", perhaps because "the soldiers' sons were already socialized into the military way of life, thus minimizing the training requirements" (1990: 50).

These considerations indicate that the first generation of Moluccan migrants already experienced a sense of displacement long before they were housed in migrant camps in the Netherlands: "the soldiers formed a distinct part of Ambonese society, isolated from negeri and urban society in Ambon as well as the host societies in garrison towns throughout the archipelago" (ibid., 397). ${ }^{13}$ This sense of isolation merely became more permanent as "The tangsi society of the Indies garrison towns was transplanted to the unfamiliar environment of provisional camps in the Netherlands, surrounded by but isolated from Dutch society" (ibid., 396). ${ }^{14}$ In reaction to their isolation and displacement, the first generation "assigned an almost sacral value to old customs" [12], even if, as a result of their military career, "they had not (yet) developed a deeper insight into the backgrounds of Moluccan culture" (ibid.). ${ }^{15}$

As a result, the adat which Moluccans adhered to in the first decades of their residence in the Netherlands, was what Bartels [1] calls "adat-by-rote: i.e., people followed, and forced their children to follow, customs and rules of whose underlying philosophy the ex-soldiers knew little" (1986: 30). More often than not, "adat had to be reconstructed, piece by piece from the little everyone remembered" (ibid.). As such, the development of adat within the Moluccan community reflects their

\footnotetext{
13 "Negeri" was the term used in the Dutch East Indies for village communities. For Chauvel's use of "Ambonese" rather than "Moluccan", see footnote 10.

14 "Tangsi" was the term used in the Dutch East Indies to refer to the garrisons that housed the Moluccan soldiers.

15 My translation from the Dutch original: "kende aan oude gebruiken een soms sacrale waarde toe"; "zelf (nog) geen diepgaand inzicht hadden verworven in de achtergronden van de Molukse cultuur.".
} 
situation as migrants who were alienated from their homeland. Identifying neither as Indonesians nor as Dutch, they had to articulate a new identity that would legitimize their position as a separate people, even as their objective of an independent Moluccan republic had not been realized. Their adat was therefore actively built anew from the fragments of what had survived their migration.

This conscious effort to articulate a new identity based on old customs was started by the first generation, but was transmitted to further generations. Especially the second generation, i.e. the soldiers' children, were interested in adat and other traditional concepts, because of the fact that their sense of alienation was even more radical than that of their parents. Like their parents, they were a visible minority in the Netherlands living isolated lives in migrant camps, and as such initially developed no sense of belonging to Dutch society. However, unlike their parents, they were born after the migration. As such, whereas a majority of their parents had at least been born and partially raised in Maluku before facing the in-between condition that characterized the Dutch migrant camps, second-generation Moluccans were born directly into this in-between condition. Maluku to them was not a lived, but an imagined past, which they had to create through the memories of their parents.

Within this context of not-belonging and having only fragmented access to the memories of the events that brought them where they are, adat was reconfigured as a form of Moluccan cultural heritage, and used as a founding principle for the articulation of a contemporary Moluccan diasporic identity based on a reconstructed past. Historian Ron Habiboe [12] relates that, within the Moluccan community, there is "an active core of people who are involved in Moluccan history, adat, language, and pela relations which they intend to tighten" (2007: 35). ${ }^{16}$ As Habiboe emphasizes, this group "forms the vanguard of people who wish to conserve, or even reinstate, ancient norms and values. Especially members of the second and third generations take part in this practice" (ibid., 34-35). ${ }^{17}$ In short, the Moluccan community uses adat as a connecting principle between the present and the past, or the before and the after of its migration. As such, adat's function for the Moluccan community is to contribute to transforming the community's involuntary in-between position into the positive articulation of a new identity.

Therefore, the separatism that was underlying the early Moluccan appropriation of adat around the time of the proclamation of the Moluccan Republic in 1950, still forms the fundament of the contemporary application by the community in the Netherlands. Adat is used as a sign of difference, that sets the Moluccan community apart both from the Indonesians and from the Dutch. As Moluccan artist Dominique Latoel expresses it in his interview for Untuk Selalu (2015), a documentary about third-generation postcolonial migrants in the Netherlands: Adat "forms the right to

\footnotetext{
16 Pela is a system that allows and disallows Moluccans to marry one another, based on their islands and villages of origin. The sentence is my translation from the Dutch original: "een actieve kern van mensen die zich bezighoudt met de Molukse geschiedenis, adat, taal,en pela-banden die men strakker wil aanhalen.".

17 My translation from the Dutch original: "vormt een voorhoede van mensen die de oude normen en waarden wil conserveren, zo niet in ere herstellen. Vooral leden van de tweede en derde generatie nemen hieraan deel.".
} 
exist of the Moluccan people and of myself as an individual" ([3]; italics added). ${ }^{18}$ Latoel's description of adat as the Moluccan right to exist makes sense when considering that the community's migration happened as a result of their failed attempt to establish an independent republic. The Moluccan identity is therefore based on a state that was never acknowledged: their right to exist as a people was denied. Adat returns this right to them, as it is applied as an inheritance from a past before their migration to the Netherlands, and before the suppression of their independence struggle by Indonesia.

This function of adat as the Moluccan right to exist is discussed in much detail in an edited volume by anthropologist Elias Rinsampessy [19]. The book is a collection of articles by Moluccan scholars, as well as interviews with Moluccans who play prominent roles in the community, including athletes, artists, church leaders and politicians. It is entitled Tussen Adat en Integratie: Vijf generaties Molukkers worstelen en dansen op de Nederlandse Aarde ("Between Adat and Integration: five generations of Moluccans wrestle and dance on Dutch soil", 2008). In this title, "adat" is juxtaposed to "integration". According to sociologist Willem Schinkel [21], the concept of "integration" is problematic to the extent that it "allows the identification of what does not belong. Western European societies diagnose themselves as under threat from immigrants they perceive as 'not yet present in society', although these immigrants are part and parcel of the social process in these societies" (2017: 2). Such diagnoses are "productive to the extent that they identify what 'society' is and who properly belongs to it" (2017: 2).

In other words, "integration" is a term reserved by a society for immigrants it deems unwelcome, as a way to suspend their participation in it. Even when immigrants are legally citizens, they can still be imagined as "not yet integrated", meaning that they are still perceived as outsiders to society. With these considerations in mind, I read the title of Rinsampessy's volume [19], "Between Adat and Integration", as an implicit criticism of the concept of integration. That is, if "integration" can be understood as referring to the unrealistic expectation which Dutch society has of its immigrants, i.e. for them to become assimilated entirely within Dutch culture; then juxtaposing "adat" to this term suggests that adat is that which stands in the way of this expectation. In short, the title indicates that there is a divide between Moluccan and Dutch identity that is difficult, perhaps impossible, to reconcile.

This divide between Moluccan and Dutch identity is explored throughout the articles and interviews that are included in the volume. For instance, during his interview, Moluccan pastor Gersom Salamony states that "adat conveys the intimate sense of belonging to a people [...], to a rumah-tangga" (2008: 219). ${ }^{19} \mathrm{He}$ adds that adat "indicates where you come from. Many say that it travels along with

\footnotetext{
18 "Untuk Selalu" is Indonesian for "forever". The sentence is my translation from the Dutch original: "die het bestaansrecht vormen van het Molukse volk en mij als individu.".

19 "Rumah-tangga" can be translated to "family" or "household", and is used here as a reference to the sense of brother and sisterhood between members of the Moluccan community. The sentence is my translation from the Dutch original: "adat beantwoordt aan de innerlijke gevoelens van het behoren tot een volk [...], de rumah-tangga.".
} 
you, wherever you go" (ibid.). ${ }^{20}$ Salamony's interpretation not only emphasizes the diasporic element of adat, by describing the term as something which travelers take with them to remember their origin. He also presents adat as an intimate concept, that signifies the relationship between Moluccans and their wider community, which he imagines as a rumah-tangga, i.e. a family or household. According to Elias Rinsampessy [20], in the Moluccan understanding of inship, the rumah-tangga is "the smallest unit of living together. It is comparable to the western "nuclear family', usually father, mother and children" (1992:42). ${ }^{21}$ By ascribing to adat this sense of belonging to a nuclear family, Salamony presents it as an intimate marker of the Moluccan community's collective identity.

This approach to adat as something intimate differs from the ways in which it was approached in the three historical case studies discussed before, to the extent that these applications were all concerned with state organization. Van Vollenhoven's study of adat was meant as a way to implement a new form of jurisdiction throughout the colony. Sukarno's and Suharto's appropriations of the term were aimed at the construction of a post-independence national identity. The objective of AMAN's approach to adat was to initiate the decentralization of the state, and claim indigenous autonomy. In all three cases, adat is an instrument used to organize society.

Salamony's description of adat stands in contrast to these public applications, to the extent that it is directed not at incorporating Moluccans into, but rather sheltering them from, the wider context of, in their case, Dutch society. That is, his understanding of adat provides the Moluccan community with the sense of belonging to a family, and reminds them that, originally, they came from elsewhere. Adat's function as an intimate, sheltering marker of identity makes sense when considering that the Moluccan community identifies as a separate people, distinct from both the Indonesians and the Dutch. As such, the articulation of their collective identity is aimed not at becoming part of any wider national context, but rather at maintaining their sense of autonomy, outside of these dominant contexts.

This interpretation of adat as an intimate affair has been a stable element of the Moluccan community throughout their history as a sociopolitical minority in the Netherlands. For instance, Habiboe [12] discusses the Dutch government's suggestion in the $1970 \mathrm{~s}$ to set up an intercultural education program for Dutch and Moluccan children. He notes that this idea led to resistance among many Moluccans, because

this would also mean that Dutch children would learn about Moluccan morals and customs [...]. They argued that these things are none of Dutch people's business, and it would only teach them "our weak spots". On top of that, there is the dilemma concerning to what extent it is allowed for adat to be orally transmitted, let alone via written text. Some elements of it are only supposed to be discussed within the context of the mata rumah, and no-one outside of

${ }^{20}$ My translation from the Dutch original: "Het geeft aan waar je vandaan komt. Velen zeggen dat het met je meegaat, waar je ook naar toe gaat.".

21 My translation from the Dutch original: "De kleinste leefeenheid is de 'rumah-tangga'. Die kan vergeleken worden met het westerse 'gezin', meestal vader, moeder en kinderen.”. 
it has the right to this knowledge..$^{22}[\ldots]$ Besides, the adat has many variants, and there are differences in emphasis per village and sometimes per family. $(62-63)^{23}$

In this citation, adat is presented not only as an intimate, but even as a secret affair. The construction of adat is seen as private to such an extent that it is not only inappropriate to communicate about it to non-Moluccans, but it is even questionable to discuss adat matters among different Moluccan mata rumahs, i.e. extended families.

This understanding of adat as something secret marks a conceptual difference to the previous analyses of colonial government policies, nationalist propaganda and indigenous resistance. Whereas these case studies concern adat as a term that is actively defined and redefined as a way to organize society, the Moluccan approach leaves the specific definition of the concept emphatically unspoken, In other words, it is in general terms clear what adat does, i.e. it forms the Moluccan community's right to exist, it provides them with a sense of belonging to a family, and so on. Meanwhile, what adat $i s$, or how exactly it does these things, remains undetermined.

The rationale supporting this undefined aspect of adat can be located in the Moluccan community's history of marginalization. As the previous case studies have shown, attempts to represent adat into a commonly acceptable set of definitions have often reduced the concept to an instrument of manipulation, whether in the context of government oppression or inter-community ethno-political violence. In each of these examples, the publicly formulated definitions of adat made the concept vulnerable to manipulation. Within this context, it makes sense that Moluccans in the Netherlands, as a sociopolitical minority, prefer to keep their definitions of adat to themselves. As long as adat's specific definition remains undetermined, it cannot be used against them or taken away from them.

These considerations imply that the Moluccan application of adat takes shape as a double movement: on the one hand, adat is explicitly declared as a form of Moluccan cultural heritage that is foundational to their separatist identity, setting them apart from both the Dutch and the Indonesians; on the other hand, the definition of adat is kept quiet, and is fragmented into intimate interpretations that are not to be shared. As such, adat is presented actively as unspecified and singular, i.e. as a phenomenon which through its multiplicity gives meaning to particular experiences within the community that cannot be generalized into any universally applicable definition.

\footnotetext{
22 "Mata rumah" is a term which, like "rumah-tangga", refers to the concept of family. According to Rinsampessy [20], a mata rumah officially is a larger, extended understanding of family: a cluster of rumah-tanggas. However, he stresses that there are various interpretations of both terms, and that they are often used interchangeably (1992: 42).

${ }^{23}$ My translation from the Dutch original: "zou namelijk inhouden dat Nederlandse kinderen eveneens kennis opdoen over de Molukse zeden en gewoonten [...]. Die zaken gaan Nederlanders niets aan en je leert ze zo alleen maar 'onze zwakke plekken' te ontdekken, vinden zij. Daarbij komt het dilemma in hoeverre de adat mondeling, laat staan schriftelijk mag worden overgeleverd. Sommige elementen ervan dienen alleen in de context van de mata rumah te worden besproken, niemand daarbuiten heeft recht op die kennis [...]. Bovendien kent de adat allerlei varianten en bestaan per dorp en soms per familie accentverschillen.".
} 
This approach resonates with Van Vollenhoven's original argument that to codify adat would be to appropriate it: "Whether it be intended or not, codification drifts in the direction of unified law" [8]. Correspondingly, if Moluccans would translate their particular attachments to the concept of adat into terms that would be comprehensible to Dutch and other people not belonging to their community, they would open up the articulation of their identity to outside evaluation and contestation. Instead, by leaving adat's definition uncertain, Moluccans enable the concept to continue functioning as a distinguishing trait that sets their community apart from its surrounding national contexts.

\section{Conclusion}

The word "adat" derives from Arabic and means custom or habit. Islamic colonists of the Indonesian territory from the thirteenth century onward introduced the term as a way to refer to indigenous customs that could not be incorporated into Islamic law. Therefore, in its early use, adat was not a particular system of law, but rather denoted that system's undetermined opposite. Because adat referred to all things beyond the accepted law, its specific meaning could take virtually any form depending on context. Its contemporary usage as an identity marker for the Moluccan migrant community in the Netherlands is a strategic reappropriation of the term as a form of self-identification, which deliberately keeps intact its original capacity as something which lacks fixed definition.

The rationale supporting this approach to adat as a deliberately indeterminate form of cultural heritage is based on the Moluccan community's marginalized position in Indonesian history, as well as in contemporary Dutch society. Their separatist identity, as a people independent from both Indonesia and the Netherlands, was never acknowledged by either of these dominant sides. Today, Maluku is an Indonesian province, and since the late 1970 s, the Moluccans in the Netherlands are Dutch citizens. The Moluccan application of adat as an indefinable element of their identity makes sense within this context. By emphasizing adat's function as an identity marker, while remaining silent about its specific meaning, Moluccans protect not only the concept, but also their identity itself from becoming a matter of wider contestation. By not defining adat, they remain in control of their own identity.

Funding Open Access funding enabled and organized by Projekt DEAL.

Open Access This article is licensed under a Creative Commons Attribution 4.0 International License, which permits use, sharing, adaptation, distribution and reproduction in any medium or format, as long as you give appropriate credit to the original author(s) and the source, provide a link to the Creative Commons licence, and indicate if changes were made. The images or other third party material in this article are included in the article's Creative Commons licence, unless indicated otherwise in a credit line to the material. If material is not included in the article's Creative Commons licence and your intended use is not permitted by statutory regulation or exceeds the permitted use, you will need to obtain permission directly from the copyright holder. To view a copy of this licence, visit http://creativecommons.org/licen ses/by/4.0/. 


\section{References}

1. Bartels, Dieter. 1986. Can the train ever be stopped again? Developments in the Moluccan community in the Netherlands before and after the hijackings. Indonesia 41: 23-45.

2. Benda-Beckmann, Franz and Keebet von. 2011. Myths and stereotypes about adat law: A reassessment of Van Vollenhoven in the light of current struggles over adat law in Indonesia. Bijdragen tot de Taal-, Land-en Volkenkunde 167/2-3: 167-195.

3. Bos, Andrea van den, Robbert Maruanaija, Ambar Surastri (dir.). Untuk Selalu. Cinemasia Filmlab, 2015. Web.

4. Bourchier, David. 2007. The romance of adat in the Indonesian political imagination and the current revival. In The Revival of Tradition in Indonesian Politics: The deployment of adat from colonialism to indigenism (eds. Jamie S. Davidson and David Henley). London and New York: Routledge, 113-129.

5. Bowen, J.R. 2003. Public reasoning across cultural pluralism. In Islam, Law and Equality in Indonesia: an anthropology of public reasoning. Cambridge University Press, 253-268.

6. Bräuchler, Birgit. 2015. The cultural dimension of peace: Decentralization and reconciliation in Indonesia. Basingstoke: Palgrave Macmillan.

7. Burgers, Herman. 2012. De Garoeda en de ooievaar: Indonesië van kolonie tot nationale staat. Leiden: KITLV Uitgeverij.

8. Burns, Peter. 1989. The Myth of Adat. Journal of Legal Pluralism 28: 1-127.

9. Chauvel, Richard. 1990. Nationalists, soldiers and separatists: The Ambonese Islands from Colonialism to Revolt, 1880-1950. Leiden: KITLV Press.

10. Fasseur, Cees. 2007. Colonial dilemma: Van Vollenhoven and the struggle between adat law and Western law in Indonesia. In The Revival of Tradition in Indonesian Politics: The deployment of adat from colonialism to indigenism (eds. Jamie S. Davidson and David Henley). London and New York: Routledge, 50-67.

11. Fitzpatrick, Daniel. 1997. Disputes and pluralism in modern Indonesian Land Law. Yale Journal of International Law 22 (1): 171-212.

12. Habiboe, Ron. 2007. De rode draad: Angst voor Nederlandse invloeden. Silsilah Maluku. Den Haag: Centraal Bureau voor Genealogie, 34-37.

13. Henley, David and Jamie S. Davidson. 2007. Radical conservatism - the protean politics of adat. In The Revival of Tradition in Indonesian Politics: The deployment of adat from colonialism to indigenism (Eds. Jamie S. Davidson and David Henley). London and New York: Routledge, 1-49.

14. Lev, Daniel S. 1972. Colonial policy and influence on the evolution of the Islamic Judiciary. In Islamic Courts in Indonesia: A study in the political bases of legal institutions. Berkeley: University of California Press, 8-30.

15. Lev, Daniel S. 1973. Judicial unification in post-colonial Indonesia. Indonesia 16, 1-37.

16. Lev, Daniel S. 1985. Colonial law and the genesis of the Indonesian state. Indonesia 40: 57-74.

17. Li, Tania M. 2007. Adat in Central Sulawesi: contemporary deployments. In The Revival of Tradition in Indonesian Politics: The deployment of adat from colonialism to indigenism (eds. Jamie S. Davidson and David Henley). London and New York: Routledge, 337-370.

18. Morfit, Michael. 1981. The Indonesian State ideology according to the new order Government. Asian Survey 21 (8): 838-851.

19. Rinsampessy, Elias (ed.). 2008. Tussen Adat en Integratie: worstelen en dansen op de Nederlandse Aarde. Stichting Muhabbat: Nijmegen.

20. Rinsampessy, Elias. 1992. Het 'traditionele' gezinstype binnen de Molukse gemeenschap. Saudara Bersaudara. Dissertation. Nijmegen: Radboud University, 39-68.

21. Schinkel, Willem. 2017. Immigrant Integration Imaginaries in Western Europe. In Imagined societies: A critique of immigrant integration in Western Europe. Cambridge University Press, 1-34.

22. Sonius, H.W.J.. "Introduction." Van Vollenhoven on Indonesian Adat Law (ed. J.F. Holleman). Dordrecht: Springer, 1981: xxix-lxvii.

23. Vel, Jacqueline. 2008. Tradition, leadership and power. In Uma politics: An ethnography of democratization in West Sumba, Indonesia, 1986-2006. Leiden: KITLV Press, 55-73.

24. Vollenhoven, Cornelis van. "Adat, Adat Law, Native Law." 1906; "The elements of Adat Law." 1906. Van Vollenhoven on Indonesian Adat Law (ed. J.F. Holleman). Dordrecht: Springer, 1981: $1-6 ; 7-23$. 
Publisher's Note Springer Nature remains neutral with regard to jurisdictional claims in published maps and institutional affiliations. 